\title{
ANALISIS FAKTOR YANG MEMPENGARUHI IMPULSE BUYING WISATAWAN DOMESTIK TERHADAP PRODUK PARIWISATA DI BIRO PERJALANAN WISATA BALI
}

\author{
Bayu Anggriawan \\ I Wayan Suardana \\ I Made Sendra \\ Email : bayuzochri@gmail.com \\ PS. S1 Industri Perjalanan Wisata \\ Fakultas Pariwisata UNUD
}

\begin{abstract}
ABSTRAK
Biro Perjalanan Wisata (BPW) yang saat ini banyak tersebar di Bali merupakan salah satu sarana pokok yang dapat dimanfaatkan oleh wisatawan sebagai konsumen dalam memudahkan melakukan perjalanan wisata. Sebagai produsen produk pariwisata tentunya BPW memiliki target untuk menuai keuntungan sebanyak-banyaknya. Salah satu caranya adalah dengan memahami polapola pembelian konsumen agar strategi, trik, dan pengualaran yang dikerahkan efektif dan efisien. Fenomena impulse buying pada era globalisasi ini marak terjadi, Indonesia sendiri menurut Nielsen.com menempati posisi 3 besar dalam jumlah konsumen yang melakukan impulse buying, setelah India dan Cina. Penelitian ini bertujuan untuk membeberkan faktor-faktor apa sajakah yang mempengaruhi impulse buying wisatawan domestik terhadap produk pariwisata BPW di Bali. Penelitian ini menggunakan pendekatan kuantitaif melalui analisis faktor dan dikombinasikan dengan pendekatan kualitatif melalui pendekatan emik untuk mengkonfirmasi ulang hasil yang didapat didalam analisis faktor. Hasil analisis faktor yang kemudian di re-confirm melalui pendekatan emik menunjukan bahwa terdapat 4 faktor yang mempengaruhi impulse buying wisatawan domestik di BPW Bali yaitu (1) faktor psikologi, (2) faktor kegiatan promosi, (3) faktor finansial, (4) faktor kekerabatan, dengan faktor yang dominan adalah faktor psikologi.
\end{abstract}

\section{Kata Kunci: Impulse Buying, Wisatawan Domestik, Biro Perjalanan Wisata.}

\section{PENDAHULUAN}

Kemajuan Bali dalam sektor pariwisata dewasa ini tentunya mengundang banyak pengusaha baik swasta atau pemerintah melakukan peruntungan di Bali salah satunya adalah Biro Perjalanan Wisata. Biro Perjalanan Wisata (BPW) merupakan salah satu sarana pokok yang dapat dimanfaatkan oleh wisatawan sebagai konsumen dalam memudahkan melakukan perjalanan wisata. Sebagai produsen produk wisata kepada wisatawan, tentunya BPW memiliki target untuk menuai keuntungan yang sebesar-besarnya melalui produk-produk wisata yang mereka jual kepada wisatawan. Untuk itu dirasa perlu memahami beberapa pola-pola pembelian konsumen,

Salah satu pola pembelian konsumen yang sebenarnya tanpa disadari hampir seluruh konsumen pernah melakukannya baik dalam pembelian ritel, produk online adalah pembelian spontan atau impulse buying. Impulse buying apabila didefenisikan secara umum adalah pembelian produk apapun itu secara seketika (Loudon dan Bitta dalam Lestari, 2014). Walaupun sudah berencana untuk membeli produk tertentu namun saat tiba di lokasi pembelian produk terkadang karena beberapa hal, membuat konsumen berniat menambahkannya dengan produk lain yang menarik atau bahkan dapat beralih ke produk lain yang baru saja ditemui dilokasi pembelian produk. Kemungkinan yang lain adalah konsumen memang belum menentukan produk yang dipilihnya dari awal dan baru akan ditentukan nanti sesampainya dilokasi pembelian produk (Rook dalam Kharis, 2011). Sebuah fenomena atau pola perilaku pembelian yang tanpa disadari banyak orang sudah mengalaminya dihidup mereka. 
Berdasarkan risetnya yang terdahulu Nielsen.com pernah merilis report bahwa di Indonesia telah terjadi penurunan pertumbuhan $10 \%$ (2003-2011) dalam jumlah konsumen yang merencanakan pembeliannya (planned buying), dan terdapat peningkatan pertumbuhan sebesar 11\% (2003-2011) dalam jumlah konsumen yang mengatakan mereka tidak pernah merencanakan barang yang akan mereka beli sebelumnya dan baru akan menentukan setelah tiba dilokasi pembelian. Selain itu hal tersebut diperkuat dengan survey terbaru oleh Nielsen.com (2013) dimana dalam survey tersebut menyebutkan Indonesia menempati posisi 3 besar dalam jumlah konsumen yang melakukan impulse buying, setelah India dan Cina. Supaya seluruh hal baik strategi, pikiran, tenaga, dan biaya tidak terbuang sia-sia tentunya BPW terkait perlu untuk mengetahui faktor-faktor apa saja yang mempengaruhi pola pembelian seperti itu sehingga seluruh strategi, pikiran, dan biaya yang telah dikeluarkan tepat sasaran dan mendatangkan keuntungan bagi BPW terkait.

Adapun rumusan masalah dalam jurnal ini yaitu:

1. Faktor-faktor apakah yang mempengaruhi impulse buying wisatawan domestik terhadap produk wisata di biro perjalanan wisata Bali?

2. Faktor-faktor apakah yang dominan mempengaruhi impulse buying wisatawan domestik terhadap produk wisata di biro perjalanan wisata Bali?

3. Mengapa wisatawan domestik melakukan impulse buying terhadap produk wisata di biro perjalanan wisata Bali?

\section{METODE}

Jurnal ini menggunakan 2 pendekatan analisis. Yang pertama adalah pendekatan kuantitatif melalui analisis faktor dengan menggunakan spss 16.0 dan dikombinasikan dengan pendekatan kualitatif melalui pendekatan emik (wawancara mendalam terhadap para pelaku impulse buying dalam penelitian ini).

Jenis analisis faktor yang digunakan dalam penelitian ini adalah analisis faktor eksploratori yang merupakan suatu teknik untuk menganalisis saling ketergantungan beberapa variabel secara simultan dengan tujuan untuk menyederhanakan dari bentuk hubungan antara beberapa variabel yang diteliti menjadi sejumlah faktor yang lebih sedikit dari pada variabel yang diteliti (Malhotra, 2006).

Dalam penelitian analisis faktor eksploratori belum terdapat konsep pegangan yang jelas dalam penentuan variabel, sehingga harus didasari dari beberapa jurnal-jurnal yang sudah sah secara akademis. Jurnal ini menggunakan variabel-variabel dari beberapa jurnal penelitian relevan terkait impulse buying.

Penentuan sampel dilakukan secara purposive sampling terhadap 147 sampel dengan kriteria responden berdasarkan dari teori-teori beberapa ahli mengenai impulse buying yaitu:

1. Siapa saja yang pernah melakukan pembelian produk wisata di BPW Bali secara seketika. Termasuk didalam nya beralih produk atau menambahkan.

2. Siapa saja yang pernah melakukan pembelian produk wisata di BPW Bali dengan sudah merencanakan untuk membeli sebuah jenis produk namun belum memutuskan merk atau pun fitur apa yang akan dibeli.

3. Siapa saja yang menemukan informasi melalui BPW lain ataupun referensi lain mengenai sebuah produk wisata, dan tanpa direncanakan tertarik untuk membeli produk wisata di BPW tersebut.

\section{HASIL DAN PEMBAHASAN}

Berdasarkan penyebaran kuesioner yang dilakukan, didapati beberapa karakteristik wisatawan domestik yang mengaku pernah melakukan impulse buying, sebagai berikut:

\begin{tabular}{|c|c|c|c|c|}
\hline No & Karakteristik & Pillihan & $\begin{array}{l}\text { Jumlah } \\
\text { (orang) }\end{array}$ & $\begin{array}{c}\text { Persentase } \\
(\%)\end{array}$ \\
\hline \multirow[t]{2}{*}{1.} & \multirow[t]{2}{*}{ Jenis Kelamin } & Pria & 77 & 53,4 \\
\hline & & Wanita & 70 & 46,6 \\
\hline \multicolumn{3}{|r|}{ Total } & 147 & 100 \\
\hline \multirow[t]{3}{*}{2.} & \multirow[t]{3}{*}{ Usia } & \multirow{3}{*}{$\begin{array}{ll}\text { a. } & 21-30 \text { tahun } \\
\text { b. } & 31-40 \text { tahun } \\
\text { c. } & >40 \text { tahun }\end{array}$} & 70 & 47,6 \\
\hline & & & 47 & 31,9 \\
\hline & & & 30 & 20,5 \\
\hline \multicolumn{3}{|r|}{ Total } & 147 & 100 \\
\hline \multirow[t]{4}{*}{3.} & \multirow{4}{*}{$\begin{array}{l}\text { Pendidikan } \\
\text { Terakhir }\end{array}$} & $\begin{array}{ll}\text { a. } & \text { SMA/Sederaj } \\
\text { at }\end{array}$ & 27 & 18,4 \\
\hline & & b. Diploma & 19 & 13 \\
\hline & & $\mathrm{S} 1$ & 79 & 53,8 \\
\hline & & S2 & 22 & 14,8 \\
\hline \multirow{4}{*}{4.} & & Total & 147 & 100 \\
\hline & \multirow[t]{3}{*}{ Asal } & $\begin{array}{ll}\text { a. } & \text { Indonesia } \\
\text { Barat }\end{array}$ & 124 & 84,4 \\
\hline & & $\begin{array}{l}\text { b. Indonesia } \\
\text { Tengah }\end{array}$ & 18 & 12,2 \\
\hline & & $\begin{array}{l}\text { Indonesia } \\
\text { Timur }\end{array}$ & 5 & 3,4 \\
\hline \multirow{8}{*}{5.} & & Total & 147 & 100 \\
\hline & \multirow[t]{7}{*}{ Pekerjaan } & \multirow{6}{*}{$\begin{array}{ll}\text { a. } & \text { Pelajar } \\
\text { b. } & \text { Peg. } \\
& \text { Pemerintah } \\
\text { c. } & \text { Swasta } \\
\text { d. } & \text { Pengusaha } \\
\text { e. } & \text { Lainnya }\end{array}$} & 18 & 12,2 \\
\hline & & & 25 & 17 \\
\hline & & & & \\
\hline & & & 65 & 44,3 \\
\hline & & & 32 & 21,9 \\
\hline & & & 7 & 4,6 \\
\hline & & Total & 147 & 100 \\
\hline
\end{tabular}


Karakteristik produk pariwisata dalam ruang lingkup impulse buying sendiri memiliki produk pariwisata dipilih yang berbeda-beda per jenis impulse buying, antara lain (1) Jenis pembelian produk wisata di biro perjalanan wisata Bali secara seketika, dapat dilihat pada tabel berikut:

\begin{tabular}{|c|c|c|c|}
\hline No & Jenis Produk Wisata & $\begin{array}{l}\text { Jumlah } \\
\text { (Orang) }\end{array}$ & $\begin{array}{c}\text { Presentase } \\
\text { Impulse Buying } \\
\text { Terhadap Produk }\end{array}$ \\
\hline 1 & Paket Wisata & 7 & $20 \%$ \\
\hline 2 & Jasa Transportasi & 20 & $57,1 \%$ \\
\hline 3 & Konvensi (MICE) & 2 & $5,7 \%$ \\
\hline 4 & Panduan Wisata & 0 & $0 \%$ \\
\hline 5 & Akomodasi (Hotel, Restoran, dll) & 2 & $5,7 \%$ \\
\hline 6 & Pengurusan Dokumen Perjalanan & 4 & $11,5 \%$ \\
\hline & Total & 35 & 100 \\
\hline
\end{tabular}

il Penelitian, 2015

(2) Jenis pembelian produk wisata dengan sudah menentukan untuk hanya membeli produk dengan merk tertentu namun sesampainya di salah satu biro perjalanan wisata Bali beralih pilihan ataupun menambahkan produk diluar dari yang telah ditentukan, produk pariwisata yang paling dominan dipilih untuk produk yang awalnya ditentukan dapat dilihat pada tabel berikut:

\begin{tabular}{|c|l|c|c|}
\hline No & \multicolumn{1}{|c|}{ Jenis Produk Wisata } & $\begin{array}{c}\text { Jumlah } \\
\text { (Orang) }\end{array}$ & $\begin{array}{c}\text { Presentase } \\
\text { Impulse Buying } \\
\text { Terhadap Produk }\end{array}$ \\
\hline 1 & Paket Wisata & 36 & $35,6 \%$ \\
\hline 2 & Jasa Transportasi & 34 & $33,7 \%$ \\
\hline 3 & Konvensi (MICE) & 0 & $0 \%$ \\
\hline 4 & Panduan Wisata & 0 & $0 \%$ \\
\hline 5 & Akomodasi (Hotel, Restoran, dll) & 31 & $30,7 \%$ \\
\hline 6 & Pengurusan Dokumen Perjalanan & 0 & $0 \%$ \\
\hline \multicolumn{2}{|c|}{ Total } & $\mathbf{1 0 1}$ & $\mathbf{1 0 0} \%$ \\
\hline \multicolumn{2}{|c|}{ Sumber: Hasil Penelitian, 2015 }
\end{tabular}

Produk yang membuat mereka beralih ingin membeli dapat dilihat pada tabel berikut:

\begin{tabular}{|c|l|c|c|}
\hline No & \multicolumn{1}{|c|}{ Jenis Produk Wisata } & $\begin{array}{c}\text { Jumlah } \\
\text { (orang) }\end{array}$ & $\begin{array}{c}\text { Presentase } \\
\text { Impulse Buying } \\
\text { Terhadap Produk }\end{array}$ \\
\hline 1 & Paket Wisata & 51 & $63 \%$ \\
\hline 2 & Jasa Transportasi & 17 & $20,98 \%$ \\
\hline 3 & Konvensi (MICE) & 0 & $0 \%$ \\
\hline 4 & Panduan Wisata & 0 & $0 \%$ \\
\hline 5 & Akomodasi (Hotel, Restoran, dll) & 13 & $16,02 \%$ \\
\hline 6 & Pengurusan Dokumen Perjalanan & 0 & $0 \%$ \\
\hline \multicolumn{2}{|r|}{ Total } & $\mathbf{8 1}$ & $\mathbf{1 0 0} \%$ \\
\hline
\end{tabular}

Produk pariwisata yang ditambahkan ke list belanja mereka dapat dilihat pada tabel berikut:

\begin{tabular}{|c|l|c|c|}
\hline No & \multicolumn{1}{|c|}{ Jenis Produk Wisata } & $\begin{array}{c}\text { Jumlah } \\
(\text { Orang) }\end{array}$ & $\begin{array}{c}\text { Presentase } \\
\text { Impulse Buying } \\
\text { Terhadap Produk }\end{array}$ \\
\hline 1 & Paket Wisata & 0 & $0 \%$ \\
\hline 2 & Jasa Transportasi & 2 & $0,03 \%$ \\
\hline 3 & Konvensi (MICE) & 0 & $0 \%$ \\
\hline 4 & Panduan Wisata & 34 & $54,83 \%$ \\
\hline 5 & Akomodasi (Hotel, Restoran, dll) & 6 & $1 \%$ \\
\hline 6 & Pengurusan Dokumen Perjalanan & 20 & $44,14 \%$ \\
\hline \multicolumn{2}{|c|}{ Total } & $\mathbf{6 2}$ & $\mathbf{1 0 0} \%$ \\
\hline
\end{tabular}

(3) Jenis pembelian produk pariwisata di biro perjalanan wisata Bali dengan sudah merencanakan untuk membeli jenis produk tertentu namun belum memutuskan merk ataupun fitur sepeti apa yang akan dibeli dalam jenis produk tersebut, dapat dilihat pada tabel produk wisata berikut:

\begin{tabular}{|c|l|c|c|}
\hline No & \multicolumn{1}{|c|}{ Jenis Produk Wisata } & $\begin{array}{c}\text { Jumlah } \\
\text { (Orang) }\end{array}$ & $\begin{array}{c}\text { Presentase Impulse } \\
\text { Buying Terhadap } \\
\text { Produk }\end{array}$ \\
\hline 1 & Paket Wisata & 17 & $15,3 \%$ \\
\hline 2 & Jasa Transportasi & 53 & $52,5 \%$ \\
\hline 3 & Konvensi (MICE) & 0 & $0 \%$ \\
\hline 4 & Panduan Wisata & 0 & $0 \%$ \\
\hline 5 & Akomodasi (Hotel, Restoran, dll) & 41 & $32,2 \%$ \\
\hline 6 & Pengurusan Dokumen Perjalanan & 0 & $0 \%$ \\
\hline \multicolumn{2}{|r|}{ Total } & $\mathbf{1 1 1}$ & $\mathbf{1 0 0} \%$ \\
\hline
\end{tabular}

(4) Jenis pembelian produk pariwisata dimana menemukan informasi mengenai produk tersebut dari referensi lain diluar dari lokasi biro perjalanan wisata terkait, lalu memutuskan untuk segera membeli produk tersebut saat itu juga di biro perjalanan terkait, dapat dilihat pada tabel berikut:

\begin{tabular}{|c|l|c|c|}
\hline No & \multicolumn{1}{|c|}{ Jenis Produk Wisata } & $\begin{array}{c}\text { Jumlah } \\
\text { (Orang) }\end{array}$ & $\begin{array}{c}\text { Presentase Impulse } \\
\text { Buying Terhadap } \\
\text { Produk }\end{array}$ \\
\hline 1 & Paket Wisata & 13 & $48,1 \%$ \\
\hline 2 & Jasa Transportasi & 11 & $40,8 \%$ \\
\hline 3 & Konvensi (MICE) & 0 & $0 \%$ \\
\hline 4 & Panduan Wisata & 0 & $0 \%$ \\
\hline 5 & Akomodasi (Hotel, Restoran, dll) & 3 & $11,1 \%$ \\
\hline 6 & Pengurusan Dokumen Perjalanan & 0 & $0 \%$ \\
\hline \multicolumn{2}{|r|}{ Total } & $\mathbf{2 7}$ & $\mathbf{1 0 0} \%$ \\
\hline
\end{tabular}

Setelah seluruh karakteristik baik reponden dan produk pariwsatanya dijelaskan secaramenyeluruh, selanjutnya adalah menganalisis data yang didapat melalui penyebaran kuesioner yang diisi oleh 147 sampel responden. Tahapan-tahapan analisis faktor dalam penelitian ini sebagai berikut:

1. Merumuskan Masalah

2. Matrik Korelasi

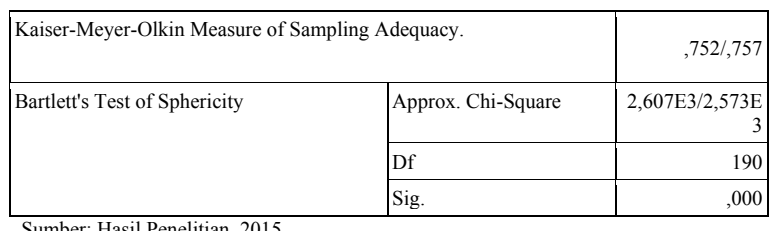

\begin{tabular}{|c|c|c|c|}
\hline \multirow{2}{*}{$\begin{array}{l}\text { Variabel } \\
\text { Kognitif (X1.1) }\end{array}$} & \multicolumn{2}{|c|}{$\begin{array}{c}\text { Nilai MSA } \\
\text { Analisis 1/2 }\end{array}$} & \multirow{2}{*}{$\begin{array}{c}\begin{array}{c}\text { Nilai Standar } \\
\text { Minimum }\end{array} \\
0,5\end{array}$} \\
\hline & 0,885 & 0,884 & \\
\hline Emosional (X1.2) & 0,858 & 0,854 & 0,5 \\
\hline Shopping Lifestyle (X1.3) & 0,689 & 0,696 & 0,5 \\
\hline Tawaran Diskon (X1.4) & 0,551 & 0,555 & 0,5 \\
\hline Various Scheme (X1.5) & 0,892 & 0,889 & 0,5 \\
\hline Income level (X1.6) & 0,790 & 0,792 & 0,5 \\
\hline Display Product (X1.7) & 0,717 & 0,714 & 0,5 \\
\hline Sales Person $(\mathrm{X} 1.8)$ & 0,665 & 0,659 & 0,5 \\
\hline Popularityof Product (X1.9) & 0,870 & 0,868 & 0,5 \\
\hline Rekomendasi dari Orang (X1.10) & 0,547 & 0,547 & 0,5 \\
\hline Festival Seasons (X1.11) & 0,461 & - & 0,5 \\
\hline Store Environment (X1.12) & 0,845 & 0,850 & 0,5 \\
\hline Visual Merchandising (X1.13) & 0,851 & 0,856 & 0,5 \\
\hline Kepemilikan Credit Card (X1.14) & 0,669 & 0,664 & 0,5 \\
\hline Time Pressure (X1.15) & 0,789 & 0,788 & 0,5 \\
\hline Atmospheric Factors (X1.16) & $\mathbf{0 , 4 8 4}$ & - & 0,5 \\
\hline Presence of Others $(\mathrm{X} 1.17)$ & 0,559 & 0,557 & 0,5 \\
\hline
\end{tabular}


Vol. 4 No. 1, 2016

\begin{tabular}{|l|l|l|l|}
\hline Orientasi dari Keluarga $(\mathrm{X} 1.18)$ & 0,778 & 0,784 & 0,5 \\
\hline Keamanan $(\mathrm{X} 1.19)$ & 0,862 & 0,867 & 0,5 \\
\hline Free Products $(\mathrm{X} 1.20)$ & 0,772 & 0,792 & 0,5 \\
\hline
\end{tabular}

Sumber: Hasil Penelitian, 2015

\section{Ekstraksi Faktor}

\begin{tabular}{|c|r|r|c|c|c|c|}
\hline \multirow{2}{*}{ Component } & \multicolumn{3}{|c|}{ Initial Eigenvalues } & \multicolumn{3}{c|}{$\begin{array}{c}\text { Extraction Sums of } \\
\text { Squared Loadings }\end{array}$} \\
\cline { 2 - 8 } & & $\begin{array}{c}\text { \% of } \\
\text { Varianc } \\
\text { e }\end{array}$ & $\begin{array}{c}\text { Cumula } \\
\text { tive \% }\end{array}$ & Total & $\begin{array}{c}\text { \% of } \\
\text { Varianc } \\
\text { e }\end{array}$ & $\begin{array}{c}\text { Cumula } \\
\text { tive \% }\end{array}$ \\
\hline 1 & 5,508 & 30,600 & 30,600 & 5,508 & 30,600 & 30,600 \\
\hline 2 & 3,869 & 21,493 & 52,092 & 3,869 & 21,493 & 52,092 \\
\hline 3 & 3,064 & 17,024 & 69,116 & 3,064 & 17,024 & 69,116 \\
\hline 4 & 1,717 & 9,540 & 78,656 & 1,717 & 9,540 & 78,656 \\
\hline
\end{tabular}

Sumber: Hasil Penelitian, 2015

\section{Rotasi Faktor}

\begin{tabular}{|c|c|c|c|c|}
\hline & \multicolumn{4}{|c|}{ Component } \\
\hline & 1 & 2 & 3 & 4 \\
\hline Kognitif (X1.1) & .905 & .066 & .059 & .147 \\
\hline Emosional (X1.2) & .852 & .048 & .042 & .156 \\
\hline Shopping Lifestyle (X1.3) & .755 & .011 & .016 & -.029 \\
\hline Tawaran Diskon (X1.4) & .044 & -.006 & .920 & .048 \\
\hline Various Scheme (X1.5) & .054 & .836 & .054 & .017 \\
\hline Income level (X1.6) & .048 & .072 & .855 & .138 \\
\hline Display Product (X1.7) & .027 & .957 & .020 & -.025 \\
\hline Sales Person (X1.8) & .095 & .916 & .071 & .054 \\
\hline Popularityof Product (X1.9) & .701 & .061 & .162 & .121 \\
\hline Rekomendasi dari Orang (X1.10) & .117 & -.015 & .119 & .888 \\
\hline Store Environment (X1.12) & .048 & .812 & .018 & .011 \\
\hline Visual Merchandising (X1.13) & .072 & .739 & .084 & .030 \\
\hline Kepemilikan Credit Card (X1.14) & .067 & .072 & .791 & .214 \\
\hline Time Pressure (X1.15) & .673 & .117 & .026 & .050 \\
\hline Presence of Others (X1.17) & .130 & -.005 & .141 & .812 \\
\hline Orientasi dari Keluarga $(\mathrm{X} 1.18)$ & .094 & .124 & .251 & .289 \\
\hline Keamanan (X1.19) & .651 & .130 & .281 & .015 \\
\hline Free Products (X1.20) & .086 & .019 & .679 & -.048 \\
\hline
\end{tabular}

5. Interpretasi Faktor

\begin{tabular}{|c|c|c|c|}
\hline No & Nama Variabel & $\begin{array}{c}\text { Loading } \\
\text { Factor }\end{array}$ & $\begin{array}{c}\text { Persentase } \\
\text { Variance }\end{array}$ \\
\hline \multirow{6}{*}{1.} & Kognitif (X1.1) & 0,905 & \multirow{6}{*}{$30,600 \%$} \\
\hline & Emosional (X1.2) & 0,852 & \\
\hline & Shopping Lifestyle (X1.3) & 0,755 & \\
\hline & Popularityof Product (X1.9) & 0,701 & \\
\hline & Time Pressure $(\mathrm{X} 1.15)$ & 0,673 & \\
\hline & Keamanan (X1.19) & 0,651 & \\
\hline \multirow{5}{*}{2.} & Various Scheme (X1.5) & 0,836 & \multirow{5}{*}{$21,493 \%$} \\
\hline & Display Product (X1.7) & 0,957 & \\
\hline & Sales Person $(\mathrm{X} 1.8)$ & 0,916 & \\
\hline & Store Environment (X1.12) & 0,812 & \\
\hline & Visual Merchandising (X1.13) & 0,739 & \\
\hline \multirow{4}{*}{3.} & Tawaran Diskon (X1.4) & 0,920 & \multirow{4}{*}{$17,024 \%$} \\
\hline & Income level (X1.6) & 0,855 & \\
\hline & $\begin{array}{l}\begin{array}{l}\text { Kepemilikan Credit Card } \\
(\mathrm{X} 1.14)\end{array} \\
\end{array}$ & 0,791 & \\
\hline & Free Products $(\mathrm{X} 1.20)$ & 0,679 & \\
\hline \multirow{3}{*}{4.} & $\begin{array}{l}\text { Rekomendasi dari Orang } \\
\text { (X1.10) }\end{array}$ & 0,888 & \multirow{3}{*}{$9,540 \%$} \\
\hline & Presence of Others (X1.17) & 0,812 & \\
\hline & 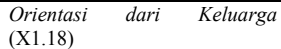 & 0,289 & \\
\hline
\end{tabular}

6. Uji Ketepatan Model

Model sudah tepat.

Dalam analisis faktor untuk menentukan faktor-faktor yang mempengaruhi impulse buying wisatawan domestik terhadap produk wisata di biro perjalanan wisata Bali, melewati beberapa tahapan yang dapat dijelaskan sebagai berikut:

1. Merumuskan Masalah

2. Matrik Korelasi

Pada matriks korelasi dapat diidentifikasikan variabel-variabel mana yang saling berhubungan/ berkorelasi dari 20 variabel yang diteliti dengan beberapa uji, yaitu Uji Bartlett's, uji Kaiser-MeyerOlkin (KMO), dan Measure of Sampling Adequacy (MSA).

Karena terdapat variabel yang tidak memenuhi standar nilai MSA $(>0,5)$, maka dilakukan kembali uji Bartlet, uji KMO dan uji MSA hingga seluruh variabel dalam penelitian ini saling berkorelasi. Analisis faktor tahap kedua seluruh variabel dinyatakan valid karena memiliki nilai MSA $>0,5$, dan dapat dilanjutkan ke tahap selanjutnya.

3. Ekstraksi Faktor

Faktor yang hendak dipilih untuk dianalisis lebih lanjut adalah terbatas pada faktor dengan nilai eigenvalue $\geq 1$ dan juga dengan cumulative variance $>60 \%$ (Malhotra, 2006). Dengan batasan ini, ada 4 faktor yang mempunyai eigenvalue $\geq 1$.

Melalui 18 variabel tersisa, terdapat 4 faktor yang memiliki eigenvalue $\geq 1$, yaitu 5,$508 ; 3,869 ; 3,064 ;$ dan 1,717 dengan memiliki nilai Cumulative eigenvalue sebesar $78,656 \%$. Hal ini berarti 18 variabel yang ada dapat dijelaskan hanya dengan 4 faktor utama.

4. Rotasi Faktor

Penelitian ini menggunakan rotasi varimax, dengan menggunakan rotasi varimax suatu variabel dapat dilihat termasuk kedalam faktor yang mana melalui loading factor tertinggi, maka matriks faktor menjadi lebih jelas dan mudah di interpretasikan. Setelah dilakukan rotasi, dapat dilihat bahwa variabel sejumlah 18 tersebut tersebar kedalam 4 (empat) faktor, yaitu:

\begin{tabular}{|c|c|c|c|c|}
\hline No & Faktor 1 & Faktor 2 & Faktor 3 & Faktor 4 \\
\hline 1. & Kognitif (X1.1) & $\begin{array}{l}\text { Various Scheme } \\
\text { (X1.5) }\end{array}$ & $\begin{array}{l}\text { Tawaran } \\
\text { Diskon } \\
\text { (X1.4) }\end{array}$ & $\begin{array}{l}\text { Rekomendasi } \\
\text { dari Orang } \\
\text { (X1.10) }\end{array}$ \\
\hline 2. & $\begin{array}{l}\text { Emosional } \\
\text { (X1.2) }\end{array}$ & $\begin{array}{ll}\begin{array}{l}\text { Display } \\
\text { (X1.7) }\end{array} & \text { Product } \\
\end{array}$ & $\begin{array}{l}\text { Income level } \\
\text { (X1.6) }\end{array}$ & $\begin{array}{l}\text { Presence of } \\
\text { Others (X1.17) }\end{array}$ \\
\hline 3. & $\begin{array}{l}\text { Shopping } \\
\text { Lifestyle (X1.3) }\end{array}$ & $\begin{array}{ll}\begin{array}{l}\text { Sales } \\
\text { (X1.8) }\end{array} & \text { Person } \\
\end{array}$ & $\begin{array}{l}\text { Kepemilikan } \\
\text { Credit Card } \\
\text { (X1.14) }\end{array}$ & $\begin{array}{ll}\text { Orientasi dari } \\
\text { Keluarga } & \\
\text { (X1.18) } & \\
\end{array}$ \\
\hline 4. & $\begin{array}{l}\text { Popularity of } \\
\text { Product (X1.9) }\end{array}$ & $\begin{array}{l}\text { Store Environment } \\
\text { (X1.12) }\end{array}$ & $\begin{array}{l}\text { Free } \\
\text { Products } \\
\text { (X1.20) }\end{array}$ & \\
\hline 5. & $\begin{array}{l}\text { Time Pressure } \\
\text { (X1.15) }\end{array}$ & $\begin{array}{l}\text { Visual } \\
\text { Merchandising } \\
\text { (X1.13) }\end{array}$ & & \\
\hline 6. & $\begin{array}{l}\text { Keamanan } \\
\text { (X1.19) }\end{array}$ & & & \\
\hline
\end{tabular}




\section{Interpretasi Faktor}

Pada dasarnya loading factor (korelasi) mengidentifikasikan korelasi antara variabel dengan faktor yang bersangkutan. Semakin tinggi loading factor, berarti semakin erat hubungan antara variabel dengan faktor tersebut. Pada penelitian ini, ada beberapa variabel yang dikeluarkan atau tidak masuk dalam model karena tidak melewati nilai minimum yang ditentukan yaitu $>0,5$. Berdasarkan hal tersebut dari 20 variabel yang telah dianalisis melalui uji MSA (Measure of Sampling Adequancy) terdapat 2 variabel yang tidak memenuhi nilai minimum $>0,5$, yaitu Festival Seasons (X1.11) dan Atmospheric Factors (X1.16) sehingga hanya menyisakan 18 variabel yang diteliti lebih lanjut didalam penelitian ini.

Dari 18 variabel yang tersisa kemudian dilakukan tahapan ekstraksi dan rotasi terhadap variabel-variabel tersebut, yang kemudian pada akhirnya terbentuk 4 faktor yang dominan dan mampu menjelaskan keseluruhan 18 variabel tersisa yang diteliti. Faktor yang merupakan gabungan dari beberapa variabel harus diberi nama, dan pemberian nama harus sesuai/relevan terhadap keseluruhan variabel yang ada dalam masing-masing faktor. Penamaan faktor dapat dilihat pada tabel berikut:

\begin{tabular}{|c|c|c|}
\hline Faktor & Penamaan Faktor & Variabel \\
\hline \multirow{6}{*}{1} & \multirow{6}{*}{ Psikologi } & Kognitif (X1.1) \\
\hline & & Emosional (X1.2) \\
\hline & & Shopping Lifestyle (X1.3) \\
\hline & & Popularityof Product (X1.9) \\
\hline & & Time Pressure (X1.15) \\
\hline & & Keamanan (X1.19) \\
\hline \multirow{5}{*}{2} & \multirow{5}{*}{ Aktivitas Promosi } & Various Scheme (X1.5) \\
\hline & & Display Product (X1.7) \\
\hline & & Sales Person (X1.8) \\
\hline & & Store Environment (X1.12) \\
\hline & & Visual Merchandising (X1.13) \\
\hline \multirow{4}{*}{3} & \multirow{4}{*}{ Finansial } & Tawaran Diskon (X1.4) \\
\hline & & Income level (X1.6) \\
\hline & & $\begin{array}{l}\text { Kepemilikan Credit Card } \\
\text { (X1.14) }\end{array}$ \\
\hline & & Free Products $(\mathrm{X} 1.20)$ \\
\hline \multirow{3}{*}{4} & \multirow{3}{*}{ Kekerabatan } & $\begin{array}{l}\text { Rekomendasi dari Orang } \\
\text { (X1.10) }\end{array}$ \\
\hline & & Presence of Others (X1.17) \\
\hline & & $\begin{array}{l}\text { Orientasi dari Keluarga } \\
\text { (X1.18) }\end{array}$ \\
\hline
\end{tabular}

6. Uji Ketepatan Model

Model dalam penelitian ini memiliki ketepatan sebesar $81 \%$ dengan tingkat kesalahan 5\%.

\section{Pendekatan Emik}

Berdasarkan hasil wawancara yang dilakukan di beberapa biro perjalanan Denpasar dan Badung yang mencoba menggali lebih dalam tanggapan-tanggapan insider (pelaku impulse buying) mengenai fenomena yang terjadi terhadap diri mereka terkait penelitian ini dan juga guna mengetahui alasan mereka melakukan impulse buying terhadap produk wisata secara lebih medalam, didapati beberapa hal yang menarik untuk memperkuat hasil analisis faktor yang sudah diolah sebelumnya:

1. Keseluruhan alasan di masing-masing jenis impulse buying yang diungkapkan insider secara garis besar sama dengan yang telah diungkapkan dalam analisis faktor sebelumnya, dengan kata lain hasil wawancara berhasil me-reconfirm hasil dari analisis faktor.

2. Terdapat beberapa faktor lain diluar dari penelitian ini diungkapkan oleh para pelaku impulse buying yang mempengaruhi impulse buying mereka terhadap produk wisata di biro perjalanan wisata Bali, yaitu: (1) mood, (2) image perusahaan, (3) kepraktisan pembelian produk, (4) dijual dalam mata uang rupiah, dan (5) fleksibilitas pemakaian produk.

\section{SIMPULAN DAN SARAN}

Berdasarkan hasil analisis yang dilakukan mengenai faktor-faktor yang mempengaruhi impulse buying wisatawan domestik terhadap produk pariwisata di biro perjalanan wisata Bali dengan menggunakan teknik analisis faktor terhadap 147 sampel dan pendekatan emik yang dilakukan di biro perjalanan wisata yang tersebar di Denpasar dan Badung terhadap insiders dari impulse buying produk pariwisata, maka dapat disimpulkan sebagai berikut:

1. Faktor-faktor yang mempengaruhi impulse buying wisatawan domestik terhadap produk wisata di biro perjalanan pariwisata terdiri dari 4 (empat) faktor yaitu: (1) faktor psikologi, (2) faktor kegiatan promosi, (3) faktor finansial, (4) faktor kekerabatan dengan faktor yang apaling dominannya adalah faktor psikologi.

2. Jika dilihat melalui pendekatan emik (pendekatan melalui sudut pandang 
para pelaku impulse buying) ada beberapa hal yang terungkap yaitu: (1) pendekatan emik yang dilakukan berhasil me-reconfirm hasil yang didapat dalam analisis faktor, (2) Terdapat beberapa faktor lain diluar dari penelitian ini diungkapkan oleh para pelaku impulse buying yang mempengaruhi impulse buying mereka terhadap produk wisata di biro perjalanan wisata Bali, yaitu mood, image perusahaan, kepraktisan pembelian produk, dijual dalam mata uang rupiah, dan fleksibilitas pemakaian produk.

Saran yang dapat diajukan berdasarkan simpulan di atas dalam upaya meningkatkan pemasaran produk wisata di biro-biro perjalanan wisata yang tersebar di Bali:

1. Berikan training kepada sales person terkait skill mereka dalam mempresentasikan suatu produk wisata ke wisatawan, karena di hampir setiap jenis impulse buying mereka adalah kunci utama yang membuat wisatawan tertarik untuk segera membeli produk tertentu.

2. Selalu meng-update kegiatan-kegiatan promosi terkait finansial, segala sesuatu yang sekiranya membuat calon pelaku impulse buying akan merasa diuntungkan dari sisi finansial, contohnya potongan harga, buy one get one, dan lain-lain.

\section{DAFTAR PUSTAKA}

Diener, E., \& Biswas-Diener, R. 2008. The science of optimal happiness. Boston: Blackwell Publishing.

Endraswara, Suwardi. 2006. Metode, Teori, Teknik Penelitian Kebudayaan: Ideologi, Epistomologi, dan Aplikasi. Yogyakarta: Pustaka Widyatama

Hair, JF et al. 2010. Multivariate Data Analysys. London: Pearson Prentice Hall

Holden, A. 1989. Environment and Tourism. London: Routledge

Soekadijo. 2000. Anatomi Pariwista. Jakarta : Gramedia 